\title{
Structure of Motor Abilities of Pre-School Children before and after Kinesiology Treatment
}

Danimir Mandić, Dragan Martinović and Vladan Pelemiš Faculty of Teacher Education, University of Belgrade

\section{Abstract}

The research included the sample of 114 pre-school children aged 6 and 7 , with average values of height $(T V=123.23 \mathrm{~cm} \pm 5.43)$ and weight $(T T=24.53 \mathrm{~kg} \pm 2.71)$. The children were divided into two groups: (E) experimental group $(n=55)$, which had an additional programme of kinesiology activities lasting for 12 weeks, and $(K)$ control group ( $n=59)$, which, apart from regular activities in physical education classes in the kindergarten did not have a programme of kinesiology activities. The aim of the research was to determine the latent structure of motor abilities before and after the application of kinesiology activities, and to determine the compatibility of factor saturation. Correlation was performed by Pearson correlation coefficient, and determination of the structure of motor activities was performed by factor analysis and by the method of principal components with bent promax rotation of isolated principal components. The Tucker index of saturation factor was used for determining the compatibility of isolated factors. Research results indicate that both in the initial and the final measurements of both tested groups, a two-dimensional structure of motor abilities was determined, consisting of coordination and strength, which could most appropriately be defined as one, general motor factor. The congruence between the isolated factors in E and K groups gained in the initial and final measurements shows that there are no differences in the structure of isolated factors. It can be concluded that motor functioning of children is still under the mechanism

of structuring movement, so after the application of kinesiology activities the same factors remained, and quality changes in the structure of motor abilities have not been detected in the tested age.

Key words: congruence of isolated factors; factor analysis; kinesiology activities; motor abilities; pre-school children. 


\section{Introduction}

Pre-school children are still in the process of habit formation in comparison to others, which will further on reflect on the quality of their lives. Integrated development of the anthropological status of pre-school children is one of the basic imperatives in the whole area of pre-school physical education. The realisation of the stated aim is possible only with a thorough understanding of internal relations and the degree of conditioning a sequence of specific dimensions of a man's biological, psychological and social status (Pelemiš, 2012). It is only on the basis of the knowledge generated in such way, and scientifically proved, that it is possible to plan and programme additional programme content in pre-school physical education, which will, in terms of quality, enable the realisation of authentic needs of each individual as a priority aim of action.

Pre-school education, as the first segment of the education system, enhances specific developmental period of children aged 1 to 7 . In this period, sensitive stages are emphasized, in which conditions are created for intensive psychomotor, affective and cognitive development of a child's personality (Džinović \& Pelemiš, 2016; Martinović et al., 2014; Prskalo et al., 2014). Complex processes of differentiation of different tissues, functional development of organic system and the process of growth, which characterise the definite morpho-functional development of a child's organism, demand quality (theoretical and methodological) approach to pedagogical and educational procedures in the pre-school period, and the one that is based on interdisciplinary scientific principles (Martinović et al., 2013). This is why it is necessary to adjust sensitive periods of development of motor abilities to potential additional implementation of physical activities with the purpose of achieving the maximum effect (Ebrahimi et al., 2013). Considering the fact that the future growth and development of a child depend on children's creativity, physical education during pre-school education and lower grades of primary school is extremely important (Tomac et al., 2012). Therefore, the World Health Organisation (WHO, 2000) has paid significant attention to insufficient physical activity of children recently, and labelled it as a risk factor, which is equal to hypertension and obesity. On the other hand, insufficient physical activity can be related to a larger number of obese children, and this is what the research points out (Martinović \& Pelemiš, 2015). That is why there is an intense need for monitoring and improving cardio-respiratory and motor status of children (Burdyukova et al., 2012, Martinović et al., 2014). Daily participation in different forms of additional physical activities has a positive effect on the growth and development of a child's organism (Eathern et al., 2013; Prskalo, 2015), and the significance of physical activities is particularly stressed in pre-school age. Contrary to the common opinion that children sufficiently participate in physical activities of middle to normal intensity, most of the recent studies prove that this is not the case (Jago et al., 2011; Leary et al., 2013). 
The term "motor abilities" is often replaced by the term "physical abilities", and it appeared in the literature on physical education written by theoreticians at the end of the 19th and the beginning of the 20th century. Apart from the term "physical abilities", there were some other terms in use, such as "movement abilities", "physical qualities" and "movement qualities". The most important term connected to motor abilities in the world is physical fitness - PF, which has been mentioned in the research (Pate, 1988). It appears in two forms (Shepard, 1982): health-related fitness - HRF and performance-related fitness - PRF. There are more terms, such as motor performance - MP. The term "motor abilities" has recently been used most frequently. In experimental research, it usually denotes operationally defined latent dimensions which emerge from a system of measuring instruments. Most simply defined, motor abilities are expressed in movement (Bala, 2010), can be described by equal parameter system, and measured by the identical group of measures in which there are analogue physiological, biochemical, cognitive and connective mechanisms (Zaciorski, 1975).

In setting the aim of this research, it was necessary to take into consideration the stated facts relating to the attempts of determining the structure of motor abilities of pre-school children by the mentioned authors, and the absence of the comparative quality parts of isolated latent dimensions after the implementation of physical activities we had come across in the literature. Therefore, the aim of the paper is to determine the latent structure of motor abilities before and after the implementation of physical exercises and to determine the compatibility of factoring reliability, so that the quality treatment can be determined, as well as some possible changes in the structure of isolated factors.

\section{Methods}

The sample of interviewees for the needs of the research was selected from the population of pre-school children by the conditioning method, i.e. quota sample. Quasi-experimental design was used in the research with non-equivalent sets and pre-test and post-test. Children attended pre-school institutions and the average age of the sample was $6.38 \pm 0.64$ years with average weight (TV=123.23 $\mathrm{cm} \pm 5.43$ ) and body mass ( $\mathrm{TM}=24.53 \mathrm{~kg} \pm 2.71)$. The research included 114 children, both girls $(\mathrm{n}=56)$ and boys $(\mathrm{n}=58)$, who had just started attending pre-school institution "Čukarica" in Belgrade at the time the research was being carried out (1st September 2015). According to the application of the experimental treatment, interviewees were divided into two homogeneous groups as follows.

The experimental group (E) consisted of children who, apart from regular physical education activities in the kindergarten "Dečji gaj", also attended additional physical education classes, lasting 35 minutes, twice a week. The type of physical exercise was directed towards the development of the basic motor abilities, and it included exercises for the development of movement coordination, agility, speed, balance, precision, flexibility, strength and elements of gymnastics. Apart from this, special 
attention was paid to the content through directed motor activities and fulfilment of all the criteria for exercising. This group included 55 participants, 30 boys and 25 girls. The questionnaire given to parents included information about physical activities of children, which they perform in their free time. The experimental group included children whose parents stated that children were not physically active apart from physical exercises in the kindergarten.

The control group $(\mathrm{K})$ consisted of children who, apart from regular physical education activities in kindergarten "Sunce", did not attend any physical education classes outside the kindergarten. This group consisted of 59 participants, 28 boys and 31 girls. In this group, children's parents provided information about whether the children attended any kind of physical education classes. K group consisted of children whose parents stated that they were not physically active and that they did not attend any sports schools outside the kindergarten.

The sample of measurement instruments for the assessment of motor abilities of pre-school children consisted of the motor skills test with proper metric characteristics (validity, reliability, representation and homogeneity), according to the adapted theoretical model of Kurelić et al. (1975a) and Gredelj et al. (1975a). This model had previously been used in research (Bala \& Popović, 2007), and tested on large samples of interviewees. The following sets of tests were applied: I For the assessment of the movement structure factors: 1) Obstacle course backwards (0.1 s); II For the assessment of the factors of motor units excitation intensity: 2) Standing long jump (cm) and 3) $20 \mathrm{~m}$ run from a standing start ( $0.1 \mathrm{~s}$ ); III For the assessment of the functional synergy factors and the regulation of the muscle tone: 4) Hand tapping (freq.) and 5) Wide legged seated forward bend $(\mathrm{cm})$; IV For the assessment of the factor of motor units excitation duration: 6) Body lift in 60s (freq.) and 7) Pull-up endurance (0.1s).

The experimental treatment (programme of directed motor activities) lasted 12 weeks. It was implemented in 24 classes lasting 35 minutes, which were organized twice a week and had the aim to improve the basic motor abilities of pre-school children. The participants from the control group were not included in the experimental treatment. The programme of application of physical exercise for developing the basic motor abilities was designed in accordance with the criteria of contemporary forms of kinesiology transformation for pre-school children. It was consistent with the physiological aspects according to the age and individual characteristics of anthropological status of participants and in line with the recommendations (Džinović, 2011) for pre-school children in a preparatory pre-school group.

The stimuli that were present within the experimental treatment were actually physical exercises, which did not last all 35 minutes during physical education treatment. We had to take into account the beginning and the end of the class and their content, so the exercises lasted between 20 and 25 minutes. The participants performed exercises according to the strict procedure of activation of muscle groups, at places set similarly to an obstacle course. The exercises were demonstrated, and 
each time different exercises were given to participants in order to activate a different group of muscles (muscles of the arms and shoulders, abdominal and spinal muscles and leg muscles). At the end of the treatment, stretching exercises were performed, as well as breathing exercises, in order for the organism to recover easily, and to allow the participants to talk about the programme of physical exercise. The middle part of the basic treatment consisted of exercising for developing complex motor tasks, coordination, agility, strength, and speed and gymnastics elements with four terms of each hypothetical motor factor. Each separate treatment of physical exercises was performed and divided into three phases, as motor activities should be directed for pre-school children: the introductory, basic (including preparatory and middle) and final part.

The first part of statistical data processing included the correlation analysis of motor abilities with initial and final measurements performed using the Pearson's correlation index. After that, the structure of motor activities was determined with initial and final measurements performed using the factor analysis and the method of principal component with bent promax rotation of isolated principal components. Further on, the analysis of factor congruence determined equality in their structure by the Tucker index of saturation factor.

\section{Results}

Table 1 presents the matrix of inter-correlation of motor variables below the diagonal in initial and final measurements in E group. The matrix shows that children who have achieved better results in initial measurement had better values of segmented speed of arm movement and shoulder area, which was already a positive relation to explosive power and repetitive power of the trunk. After the applied physical exercise treatment in E group, no significant changes were found in correlation, in terms of coordination. It still correlates, mathematically negatively, but logically positively (inverse metric), with the same variables for the assessment of explosive power, so children with higher values of repetitive power of the trunk have achieved better values in statistical strength of arms and shoulders.

Table 1

Matrix of inter-correlation of motor variables for the experimental group (E) in the initial and final measurements

\begin{tabular}{lccccccc}
\hline Variable & 1 & 2 & 3 & 4 & 5 & 6 & 7 \\
\hline Obstacle course backwards (sec.) & $\mathbf{1 . 0 0 0}$ & -.150 & .129 & $-.306^{*}$ & -.043 & -.154 & $-.295^{*}$ \\
Standing long jump (cm.) & -.147 & $\mathbf{1 . 0 0 0}$ & $-.341^{*}$ & .148 & .007 & .162 & .167 \\
20m run from a standing start (sec.) & .098 & -.237 & $\mathbf{1 . 0 0 0}$ & -.004 & -.042 & -.106 & $-.270^{*}$ \\
Hand tapping (freq.) & $-.278^{*}$ & -.032 & -.032 & $\mathbf{1 . 0 0 0}$ & .168 & .187 & .016 \\
Wide legged seated forward bend (cm.) & -.048 & -.014 & .090 & $.297^{*}$ & $\mathbf{1 . 0 0 0}$ & .013 & .052 \\
Body lift in 60s (freq.) & -.139 & .110 & -.121 & .161 & .016 & $\mathbf{1 . 0 0 0}$ & $.422^{* *}$ \\
Pull-up endurance (sec.) & $-.254^{*}$ & .102 & $-.307^{*}$ & .057 & .026 & $.437^{* *}$ & $\mathbf{1 . 0 0 0}$
\end{tabular}

Legend: There is no statistically significant correlation; ${ }^{*}$ - Statistically significant correlation in the range $p<0.05$; ** - Statistically significant correlation in the range $p<0.01$. 
Mandić, Martinović and Pelemiš: Structure of Motor Abilities of Pre-School Children before ...

Table 2

Matrix of inter-correlation of motor variables for the control group $(K)$ in the initial and final measurements

\begin{tabular}{lccccccc}
\hline Variable & 1 & 2 & 3 & 4 & 5 & 6 & 7 \\
\hline Obstacle course backwards & $\mathbf{1 . 0 0 0}$ & -.214 & .053 & .154 & .184 & -.089 & -.120 \\
Standing long jump & -.185 & $\mathbf{1 . 0 0 0}$ & .048 & .018 & .067 & .115 & .162 \\
20m run from a standing start & .143 & .044 & $\mathbf{1 . 0 0 0}$ & $.251^{*}$ & .219 & $.259^{*}$ & .122 \\
Hand tapping & .213 & .080 & .155 & $\mathbf{1 . 0 0 0}$ & .030 & .016 & -.087 \\
Wide legged seated forward bend & .154 & .038 & .150 & -.025 & $\mathbf{1 . 0 0 0}$ & .081 & -.170 \\
Body lift in 60s & -.059 & .123 & $.260^{*}$ & .069 & .133 & $\mathbf{1 . 0 0 0}$ & .234 \\
Pull-up endurance & -.096 & .164 & .092 & .058 & $-.263^{*}$ & .248 & $\mathbf{1 . 0 0 0}$ \\
\hline
\end{tabular}

The matrix of inter-correlation of motor variables of $\mathrm{K}$ group in the initial measurement (values below the diagonal) shows that children with greater values of repetitive power of the trunk achieved lower results in explosive power. The fact is that children with greater strength of arms and shoulders are less flexible. The final measurement, considering the fact that children did not engage in any other form of physical activities apart from the regular programme of physical education in the kindergarten, showed that there were no significant changes. Nevertheless, children with better explosive power had worse segmental speed of movements of the arm and repetitive power of the trunk.

The obtained matrices of inter-correlations of the tested variables were further on factorised by the method of principal components. Significant principal components underwent the process of promax rotation. The critera for extracting the significant factors consisted of the Kaiser-Guttman (KG) criterion and the Cattell scree criterion, so the interpretation of the factors was performed taking into consideration both criteria, based on the orthogonal, i.e. skew projections. After the inter-correlation matrices were factorised, in accordance with the KG criteron, there were mostly two, and in the case of $\mathrm{K}$ group, three factors. Considering the fact that the second criterion was the Cattell scree test, based on the point of inflexion of the Scree Plot diagram curve, it was decided that only two principal components were significant for defining the entire motor area. Therefore, the shown analyses will be limited to two extracted factors.

Table 3

Factor analysis of the experimental group $(E)$ in the initial measurement

\begin{tabular}{lccccccc}
\hline Variable & & $\mathrm{H} 2$ & $\mathrm{~h}^{2}$ & $\mathrm{~A} 1$ & $\mathrm{~A} 2$ & $\mathrm{~F} 1$ & $\mathrm{~F} 2$ \\
\hline Obstacle course backwards & $\mathbf{- . 5 6 9}$ & -.242 & .383 & -.388 & -.426 & -.453 & -.485 \\
Standing long jump & .384 & -.340 & .263 & $\mathbf{. 5 0 6}$ & -.191 & .477 & -.114 \\
20m run from a standing start & $\mathbf{- . 5 1 6}$ & $\mathbf{. 4 3 5}$ & .455 & $\mathbf{- . 6 6 9}$ & .236 & -.633 & .134 \\
Hand tapping & .393 & .692 & .633 & .013 & .793 & .134 &. $\mathbf{7 9 5}$ \\
Wide legged seated forward bend & .131 & .693 & .497 & -.220 & $\mathbf{. 7 0 4}$ & -.113 & .671 \\
Body lift in 60s & .650 & -.026 & .423 & $\mathbf{. 5 9 0}$ & .199 & $\mathbf{. 6 2 0}$ & .288 \\
Pull-up endurance &. $\mathbf{7 4 1}$ & -.173 & .578 & $\mathbf{. 7 4 1}$ & .091 & $\mathbf{. 7 5 5}$ & .203 \\
\hline Eigen value & 1.880 & 1.352 & & & & & $\mathrm{r}=.152$ \\
\% of Variance $=46.17 \%$ & 26.85 & 19.31 & & & & & \\
\hline
\end{tabular}

Legend: $\mathrm{H}$ - principal component; $\mathrm{h}^{2}$ - communality; $\mathrm{A}$ - matrix of composition; $\mathrm{F}$ - matrix of structure; Eigen value - characteristic root; \% of Variance - percentage of the explained variance of the suitable principal component; $r$-correlation coefficient between the significant factors. 
Table 4

Factor analysis of the experimental group (E) in the final measurement

\begin{tabular}{lccccccc}
\hline Variable & $\mathrm{H} 1$ & $\mathrm{H} 2$ & $\mathrm{~h}^{2}$ & $\mathrm{~A} 1$ & $\mathrm{~A} 2$ & $\mathrm{~F} 1$ & $\mathrm{~F} 2$ \\
\hline Obstacle course backwards & $\mathbf{- . 5 9 0}$ & -.322 & .452 & -.315 & $\mathbf{- . 5 2 8}$ & -.433 & $\mathbf{- . 5 9 8}$ \\
Standing long jump & $\mathbf{5 5 2}$ & -.250 & .368 & $\mathbf{. 6 1 3}$ & -.033 & $\mathbf{. 6 0 5}$ & .104 \\
20m run from a standing start & $\mathbf{- . 5 2 9}$ & $\mathbf{. 4 6 3}$ & .494 & -.716 & .245 & $\mathbf{- . 6 6 1}$ & .085 \\
Hand tapping & .422 & $\mathbf{. 7 0 2}$ & .671 & -.047 & $\mathbf{. 8 2 8}$ & .138 & $\mathbf{. 8 1 8}$ \\
Wide legged seated forward bend & .167 & $\mathbf{. 5 0 8}$ & .286 & -.152 & $\mathbf{. 5 4 8}$ & -.029 & $\mathbf{. 5 1 4}$ \\
Body lift in 60s & $\mathbf{. 6 1 4}$ & -.031 & .378 & $\mathbf{. 5 3 9}$ & .199 & .583 & .320 \\
Pull-up endurance & $\mathbf{. 6 9 0}$ & -.245 & .536 & $\mathbf{. 7 2 6}$ & .023 & $\mathbf{. 7 3 2}$ & .186 \\
\hline Eigen value & 1.992 & 1.192 & & & & & $\mathrm{r}=.254^{*}$ \\
\% of Variance $=45.49 \%$ & 28.45 & 17.04 & & & & & \\
\hline
\end{tabular}

In the initial and final measurements in E group (Tables 3 and 4) two significant components were isolated, which, in the initial measurement, explained $46.17 \%$, and in the final measurement $45.49 \%$ of the mutual variability of the entire tested motor area. The analysis of communalities of the tested motor variables indicate that the greatest mutual variability of the isolated factors is affected by the variables for the assessment of functional synergy and muscle tone regulation factors, as well as variables for the assessment of the factors of motor units excitation intensity, both in the initial and final measurements. This is in accordance with the matrix of intercorrelation in E group. Rotation of the principal components into a better parsimony position before and after the additional programme of physical exercise provided a clearer solution, upon which the interpretation of the structure and the composition was performed, and the given factors were identified. High parallel projections of the first isolated factor were mainly influenced by the same variables: variables for the estimation of explosive, statistical and repetitive power (pull-up endurance, $20 \mathrm{~m}$ run from a standing start, body lift in 60s, standing long jump), so this factor in the initial and final measurement can be named as the General strength factor. The structure of the second factor had the greatest parallel projections in both measurements in variables for estimating functional synergy and tonus regulation of musculature (Hand tapping and Wide legged seated forward bend), and the variables for estimating movement structures (Obstacle course backward). This is the reason why the second isolated factor can be named as the Complex motor activities factor. Based on the Pearson's coefficient of correlation, it was determined that between the first and the second named factors, there was a positive, but not statistically significant relation in the initial measurement, and positive and statistically significant relation in the final measurement. It can be said that strong children achieve better results in complex motor activities both in the initial and final measurements.

Tables 5 and 6 present factor analysis of the motor area of $\mathrm{K}$ group in the initial and final measurements. During isolation of the significant factors, two significant components were obtained, which explained mutual variability of $42.86 \%$ in the initial, 
Mandić, Martinović and Pelemiš: Structure of Motor Abilities of Pre-School Children before ...

Table 5

Factor analysis of the control group $(K)$ in the initial measurement

\begin{tabular}{lccccccc}
\hline Variable & $\mathrm{H} 1$ & $\mathrm{H} 2$ & $\mathrm{~h}^{2}$ & $\mathrm{~A} 1$ & $\mathrm{~A} 2$ & $\mathrm{~F} 1$ & $\mathrm{~F} 2$ \\
\hline Obstacle course backwards & .018 & $\mathbf{. 7 0 3}$ & .494 & $\mathbf{- . 4 3 0}$ & .539 & -.426 & $\mathbf{5 5 6}$ \\
Standing long jump & $\mathbf{. 4 3 6}$ & -.325 & .295 & $\mathbf{. 5 4 3}$ & .019 & $\mathbf{. 5 4 3}$ & .023 \\
20m run from a standing start & $\mathbf{. 6 1 2}$ & .386 & .524 & .231 & $\mathbf{. 6 8 4}$ & .235 & .686 \\
Hand tapping & .392 & .304 & .246 & .112 & $\mathbf{. 4 8 2}$ & .115 & .483 \\
Wide legged seated forward bend & .093 & $\mathbf{. 6 0 5}$ & .375 & -.310 & $\mathbf{. 5 5 0}$ & -.307 & $\mathbf{. 5 2 8}$ \\
Body lift in 60s & $\mathbf{. 7 1 4}$ & -.007 & .510 & $\mathbf{. 5 5 9}$ & .442 & $\mathbf{. 5 6 1}$ & $\mathbf{. 4 4 5}$ \\
Pull-up endurance & $\mathbf{. 5 5 4}$ & $\mathbf{- . 5 0 0}$ & .557 & $\mathbf{. 7 4 5}$ & -.043 & $\mathbf{. 7 4 5}$ & -.038 \\
\hline Eigen value & 1.544 & 1.457 & & & & & $\mathrm{r}=.006$ \\
\% of Variance $=42.86 \%$ & 22.05 & 20.81 & & & & & \\
\hline
\end{tabular}

Table 6

Factor analysis of the control group $(K)$ in the final measurement

\begin{tabular}{lccccccc}
\hline Variable & $\mathrm{H} 1$ & $\mathrm{H} 2$ & $\mathrm{~h}^{2}$ & $\mathrm{~A} 1$ & $\mathrm{~A} 2$ & $\mathrm{~F} 1$ & $\mathrm{~F} 2$ \\
\hline Obstacle course backwards & -.335 & $\mathbf{. 5 9 8}$ & .470 & $\mathbf{- . 5 0 8}$ & .491 & -.479 & .461 \\
Standing long jump & $\mathbf{. 5 1 7}$ & -.184 & .301 & $\mathbf{. 5 5 0}$ & -.043 & $\mathbf{. 5 4 7}$ & -.011 \\
20m run from a standing start & $\mathbf{. 5 5 2}$ & $\mathbf{. 5 5 9}$ & .617 & .347 & $\mathbf{. 6 8 5}$ & .388 & $\mathbf{. 7 0 5}$ \\
Hand tapping & .093 & $\mathbf{. 5 4 9}$ & .310 & -.086 & $\mathbf{. 5 5 5}$ & -.053 & $\mathbf{. 5 5 0}$ \\
Wide legged seated forward & & & & & & & \\
bend & .094 & $\mathbf{. 6 0 9}$ & .380 & -.105 & $\mathbf{. 6 1 4}$ & -.068 & $\mathbf{. 6 0 7}$ \\
Body lift in 60s & & & & & & & \\
Pull-up endurance & $\mathbf{. 6 9 6}$ & .107 & .496 & $\mathbf{. 6 2 8}$ & .285 & $\mathbf{. 6 4 5}$ & .322 \\
\hline Eigen value & $\mathbf{. 6 0 2}$ & -.324 & .467 & $\mathbf{. 6 7 5}$ & -.157 & $\mathbf{. 6 6 5}$ & -.117 \\
\% of Variance $=43.44 \%$ & 1.549 & 1.492 & & & & & $\mathrm{r}=.060$ \\
\hline
\end{tabular}

and $43.44 \%$ in the final measurement. The variables for estimating the strength and the structure of movement had the greatest influence on the mutual variable for the defined factors both in the initial and final measurements. The variables for estimating statistical, repetitive and explosive power, as well as the factor of coordination, had high parallel projections for the first isolated factor, both in the initial and final measurements. In both cases, this factor can be named as the General strength and coordination factor. The variables for estimating explosive power, flexibility and repetitive power had greatest parallel projections on the second factor in both cases, but not at the same level. This is the reason why the second factor can be named as the Strength and flexibility factor. In K group there is a positive, but statistically insignificant correlation between the first and second factor in the initial and final measurements.

After isolating the principal components of the motor area and promax rotation, we determined the adjustment of factors by applying the analysis of factor congruence.

We can conclude from Table 7 that between the first defined factor from the initial and final measurements in E group, which was named the General strength factor, significant structural difference was not determined, considering the fact that the 
Tucker index of saturation factor was 0.991 . The second isolated factor in E group also indicates that there is no significance in the structure of this factor between the initial and final measurements, i.e. that this is the same factor. The congruence between isolated factors in $\mathrm{K}$ group obtained in the initial and final measurements also point Table 7

Factor congruence of motor area for groups $E$ and $K$

\begin{tabular}{|c|c|c|c|c|c|c|c|c|}
\hline \multirow{3}{*}{$\begin{array}{l}\text { Group } \\
\text { Variable }\end{array}$} & \multicolumn{4}{|c|}{ Experimental (E) } & \multicolumn{4}{|c|}{ Control (K) } \\
\hline & \multicolumn{2}{|c|}{$\mathrm{A} 1$} & \multicolumn{2}{|c|}{$\mathrm{A} 2$} & \multicolumn{2}{|c|}{$\mathrm{A} 1$} & \multicolumn{2}{|c|}{$A 2$} \\
\hline & 1 & 2 & 1 & 2 & 1 & 2 & 1 & 2 \\
\hline Obstacle course backwards & -.388 & -.315 & -.426 & -.528 & -.430 & -.508 & .559 & .491 \\
\hline Standing long jump & .506 & .613 & -.191 & -.033 & .543 & .550 & .019 & -.043 \\
\hline $20 \mathrm{~m}$ run from a standing start & -.669 & -.716 & .236 & .245 & .231 & .347 & .684 & .685 \\
\hline Hand tapping & .013 & -.047 & .793 & .828 & .112 & -.086 & .482 & .555 \\
\hline Wide legged seated forward bend & -.220 & -.152 & .704 & .548 & -.310 & -.105 & .530 & .614 \\
\hline Body lift in $60 \mathrm{~s}$ & .590 & .539 & .199 & .199 & .559 & .628 & .442 & .285 \\
\hline Pull-up endurance & .741 & .726 & .091 & .023 & .745 & .675 & -.043 & -.157 \\
\hline $\mathrm{Rc}$ & \multicolumn{2}{|c|}{.991} & \multicolumn{2}{|c|}{977} & \multicolumn{2}{|c|}{.965} & \multicolumn{2}{|c|}{.980} \\
\hline
\end{tabular}

Legend: A - composition of factors; Rc - congruence coefficient

to the fact that there are no differences in the structure of the isolated factors.

\section{Discussion}

The latent motor area encompasses human motor abilities which are engaged in solving motor tasks and which condition successful movement. The processes of anthropological dimensions are complex, and they consist of many factors which are present in the structure of human motor apparatus and which more or less depend on each other. The basic problem in most research is defining the number of latent dimensions, i.e. determining the structure of motor abilities of children, considering significant methodological problems occurring in testing on the one hand, and the expressed cause and effect relationship of motor, cognitive, conative and other anthropological characteristics of children on the other hand. In recent research of latent motor area on an older sample of respondents it has been discovered that there is a number of basic and specific motor abilities. Most literature, both in the world and in our country (Aleksandrović et al., 2007; Fleishman, 1964; Rodić, 1997), states that in the latent area of human motor area there are basic motor abilities: strength, speed, coordination, flexibility, precision, balance and endurance. This does not mean that the examined area is limited to the stated abilities, because the research can prove the existence of some other latent dimensions as well. The basic models of motor dimensions first designed in our region (Gredelj et al., 1975b; Kurelić et al., 1975b; Metikoš et al., 1979) are still in use in research in Europe and the USA. It points to a hierarchical organisation of motor abilities and stresses the role of central physiological regulation mechanisms in motor activities when we talk about teenagers 
and young people. It can be said that the two established models are still widely used, especially the second one. In any case, they are not suitable for pre-school children. Since there is no better suitable model, most research involving pre-school children is based on the adaptation of these two models. One of these tested models is used in research involving lower primary school children, aged 6 to 10 (Bala, 1981), and in research involving pre-school children (Bala, 2002).

The most frequent problem in determining the structure of motor abilities of preschool children is an insufficient amount of information about them, as well as the metric value of the tests which are used for the assessment of some abilities. This resulted in the fact that in majority of research, latent dimensions were determined, which presented the frame for determining the structure of the motor area, and this again led to defining a great number of latent dimensions, some of which present identical abilities, but are named differently by the researchers. The latent structure of children aged 6 to 10 was not given sufficient attention. Most of the findings of the research carried out in Slovenia (Pišot \& Planinšec, 2010; Strel \& Štum, 1981a) show that motor area of children is less differentiated than that of adults. The main reason is that children at this age react with their whole body and mind to motor stimuli, and this leads to instability of the general motor structure, which develops fast. Another reason is an insufficient number of measurement approaches which would measure the motor status of children (Bala, 2007). The eminent experts in the field of kinesiology have observed the motor status of pre-school children from the aspect of structure of some areas of anthropological dimensions (Fisher et al., 2005; Sabo, 2002). All the authors agree that there are improvements caused by additional physical exercises, which are significant for improving the personality and health status of children.

When the results of research involving pre-school children are compared in the initial and final measurements, it can be concluded that there is a two-dimensional structure of motor abilities of children, consisting of coordination and power. It can most accurately be defined as the General motor factor. These results are accounted for by the extent of communalities in the investigated motor area in the tested groups, concerning the initial and final measurements. It has been detected that the variables for the assessment of statistical, explosive and repetitive power and variables for the assessment of coordination had the greatest parallel projections on the first and the second factor in both groups. Other variables had a smaller influence. The variable for the assessment of explosive power of lower extremities (Standing long jump), and the variable for the assessment of the segmental speed of arm movement (Hand tapping), which both belong to the domain of coordination, might be described by the fact that these motor tests require the first coordinated movement performance. This would belong to small children's motor skills developed as a result of their computer competence, and only after successfully completed structure of the whole task, there is the energetic component, which a child should manifest with the maximum excitation of motor units (Bala et al., 2009; Pelemiš, 2016). These are the reasons why motor 
functioning of children is still under the mechanism of movement structure, so coordination is acting as a general, and strength as a separate factor. These two factors are connected, particularly after the additional programme of physical activities in E group, so we can talk about one factor referred to as the General motor factor. The greatest similarities to these findings were obtained in the research carried out by Katic et al. (1994). The general motor factor and motor behaviour of small children, which are of universal character, have been described in earlier research (Bala, 1981; Bala \& Nićin, 1997; Perić, 1991). However, the opposite findings about differentiation of motor abilities of children have been presented by Slovenian (Planinšec, 1995; Rajtmajer \& Proje, 1990; Strel \& Šturm, 1981b), Russian (Popescu et al., 2009) and Serbian (Ivanović, 2007) authors. Research carried out by Pišot and Planinšec (2010) with a greater set of motor tests for this age of respondents and in which they isolated a greater number of factors, shows that most of the isolated dimensions cover the area of different models of coordination. This research also showed that there is a significant relationship between the element of coordination and speed of alternative movements of children.

\section{Conclusion}

From the tested sample it cannot be clearly defined which factors make the structure of the motor area in pre-school age. Research results showed that the motor area is of a two-dimensional type, composed of strength and coordination. A clearly defined motor area of pre-school aged children has not been proved yet, considering the fact that some hypothetical motor factors and intensity and duration of motor units excitation are defined in the tested age as a part of coordination. Therefore, we are still talking about motor behaviour, which is of a general type. These are the reasons, despite the additional application of physical activities, that there were no qualitative changes in the motor structure in the experimental group. The authors point out that physical education in pre-school age, for the purpose of successful development of motor behaviour of children, should be directed towards development of coordination tasks, because a great part of motor behaviour in pre-school age is still governed by the mechanism for movement structure.

\section{References}

Aleksandrović, M., Georgiev, G., Okičić, T, Madić, D., \& Malezanov, N. (2007). Basic motor skills structure in 12-year old water polo players and non-sportsmen. Serbian Journal of Sports Sciences, 1(3), 79-88.

Bala, G. (1980). Struktura i razvoj morfoloških i motoričkih dimenzija dece SAP Vojvodine. Novi Sad: Fakultet fizičke kulture Univerziteta u Novom Sadu.

Bala, G. (1981). Struktura i razvoj morfoloških i motoričkih dimenzija dece SAP Vojvodine. Novi Sad: OOUR Institut fizičke kulture. 
Bala, G. (2002). Strukturalne razlike motoričkih sposobnosti dečaka i devojčica u predškolskom uzrastu. Pedagoška stvarnost, 48(9-10), 744-752.

Bala, G. (2007). Morfološke karakteristike predškolske dece. In G. Bala (Ed.), Antropološke karakteristike i sposobnosti predškolske dece (pp.31-66). Novi Sad: Fakultet sporta i fizičkog vaspitanja Univerziteta u Novom Sadu.

Bala, G. (2010). Metodologija kineziometrijskih istraživanja sa posebnim osvrtom na motorička merenja. Novi Sad: Fakultet sporta i fizičkog vaspitanja.

Bala, G., Jakšić, D., \& Popović, B. (2009). Relacije antropoloških karakteristika i sposobnosti predškolske dece. In G. Bala (Ed.), Trend relacija morfoloških karakteristika i motoričkih sposobnosti predškolske dece (pp. 61-113). Novi Sad: Fakultet sporta i fizičkog vaspitanja Univerziteta u Novom Sadu.

Bala, G., \& Nićin, Đ. (1997). Motor behaviour of pre-school children under the influence of an unconventional sports educational model. In Proceedings of the Third International Symposium Sport of the Young, Bled, Slovenia (pp. 64-69). Ljubljana: Faculty of Sport University of Ljubljana.

Bala, G., \& Popovic, B. (2007). Motor skills of preschool children. In G. Bala (Ed.), Anthropological characteristics and abilities of preschool children (pp. 101-151). Novi Sad: Faculty of Sport and Physical Education University of Novi Sad.

Burdyukova, E. V., Pustovalov, D. A., Oranskaya, A. N., Pertsov, S. S., \& Gurevich, K. G. (2012). Mechanisms of maladaptation to physical exercise in Moscow shoolchildren. Bulletin of Experimental Biology and Medicine, 153(4), 428-430.

Džinović, D. (2011). Metodika fizičkog vaspitanja. Beograd: Učiteljski fakultet.

Džinović, D., \& Pelemiš, V. (2016). Monitoring fizičkog vaspitanja dece. Beograd: Draslar partner.

Eathern, N., Morgan, J. P., \& Lubans, R. D. (2013). Improving the fitness and physical activity levels of primary school children: Results of the Fit-4-Fun group randomized control trial. Preventive Medicine, 56(1), 12-19.

Ebrahimi, K., Nasiri, M., \& Salehian, M. H. (2013). The impact of technology and early childhoods' motor experiences on the development of children's motor-perceptual abilities. Medicina dello sport, 66(2), 223-229.

Fisher, A., Reilly, J. J., Kelly, L. A., Montgomery, C., Williamson, A., Paton, J. Y., \& Grant, S. (2005). Fundamental movement skills and habitual physical activity in young children. Medicine \& Science in Sports \& Exercise, 37(4), 684-692.

Fleishman, E. A. (1964). The structure and measurement of physical fitness. Englewood Cliffs, NJ: Prentice Hall.

Gredelj, M., Metikoš, D., Hošek, A., \& Momirovič, K. (1975). Model hijerarhijske strukture motoričkih sposobnosti, i rezultati dobijeni primjenom jednog neoklasičnog postupka za procenu latentnih dimenzija. Kineziologija, 5(1-2), 7-82.

Ivanović, M. (2007). Morfološki i motorički sklop kod devojčica (stariji predškolski uzrast). Zbornik radova Visoke škole strukovnih studija za obrazovanje vaspitača, 1(1), 42-56.

Jago, R., Davison, K. K., Brockman, R., Page, A. S., Thompson, J. L., \& Fox, K. R. (2011). Parenting styles, parenting practices, and physical activity in 10- to 11-year olds. Preventive Medicine, 52(1), 44-47. 
Katić, R., Zagorac, N., Živičnjak, M., \& Hraski Ž. (1994). Taxonomic analysis of morphological/motor characteristics in seven-year old girls. Collegium Antropologicum, $18(1), 141-154$.

Kurelić, N., Momirović, K., Stojanović, M., Šturm, J., Radojević, Đ., \& Viskić-Štalec, N. (1975). Struktura i razvoj morfoloških i motoričkih dimenzija omladine. Beograd: Institut za naučna istraživanja. Fakultet fizičkog vaspitanja Univerziteta u Beogradu.

Leary, J. M., Lilly, C. L., Dino, G., Loprinzi, P. D., \& Cottrell, L. (2013). Parental Influences on 7-9 year olds' physical activity: A conceptual model. Preventive Medicine, 56 (5), 341344. https://doi.org/10.1016/j.ypmed.2013.02.005

Martinović, D., Dejić, M., Mandić, D., Pelemiš, V., Pelemiš, M., \& Ujsasi, D. (2014). Computer Based BIA Method in Preschool Education. In C. A. Bulucea, N. Mastoraks, P. Revesz, P. M. Pardalos, \& A. Fukasawa (Eds.), Proceedings of the 2nd International Conference on Education and Modern Educational Technologies (pp. 81-85). Athens: EUROPMENT.

Martinović, D., Džinović, D., \& Pelemiš, V. (2014). Information technologies in establishing morphological dimensions determined by sex. Journal Plus Educatia, 10(1), 189-193.

Martinović, D., \& Pelemiš, V. (2015). Kinantropološki aspekti učenika. Beograd: Draslar partner.

Martinović, D., Pelemiš, V., Branković, D., Živanović, V., \& Pelemiš, M. (2013). Software Tools for the Bioelectrical Impedance Method of Children Selection in Sport. In 4th European Conference of Computer Science, "Recent Advances in Information Science '13" (pp. 283-287). Paris: EUROPMENT.

Metikoš, D., Gredelj, M., \& Momirović, K. (1979). Struktura motoričkih sposobnosti. Kineziologija, 9(1-2), 25-50.

Pate, R. R. (1988). The evolving definition of physical fitness. Quest, 40(3), 174-179. https:// doi.org/10.1080/00336297.1988.10483898

Pelemiš, V. (2012). Kvantitativne i kvalitativne karakteristike morfološkog i motoričkog prostora dečaka i devojčica predškolskog uzrasta. (Master's thesis). Novi Sad: Fakultet sporta i fizičkog vaspitanja Univerziteta u Novom Sadu.

Pelemiš, V. (2016). Uticaj dodatnog programa fizičkog vežbanja na morfološki i motorički status predškolske dece (Doctoral dissertation). Novi Sad: Fakultet sporta i fizičkog vaspitanja Univerziteta u Novom Sadu.

Perić, D. (1991). Komparativna analiza metodoloških sistema eksplikacije biomotoričkog statusa dece predškolskog uzrasta. (Doctoral dissertation). Beograd: Fakultet fizičke kulture Univerziteta u Beogradu.

Pišot, R., \& Planinšec, J. (2010). Motor structure and basic movement competences in early child development. Annales Kinesiologiae, 1(2), 145-167.

Planinšec, J. (1995). Relacije med nekaterimi motoričnimi in kognitivnimi sposobnostimi petletnih otrok (Master's thesis). Ljubljana: Fakulteta za šport Univerza v Ljubljani.

Popeska, B., Georgiev, G., \& Mitevski, O. (2009). Structure of motor space in children at 7 year age. Научни трудови на Русенски Университет (Naučni radovi na Rusenskom Univerzitetu), 48(8), 19-24. 
Prskalo, I. (2015). Kinesiology of Free Time. Croatian Journal of Education, 17(1), 219-228.

Prskalo, I., Horvat, V., \& Hraski, M. (2014). Play and Children's Kinesiological Activities: A Precondition for Making Daily Exercise a Habit. Croatian Journal of Education, 16(1), 57-68.

Rajtmajer, D., \& Proje, S. (1990). Analiza zanesljivosti in faktorska struktura kompozitnih testov za spremljanje in vrednotenje motoričnega razvoja predškolskih otrok. Šport, 38(12), 48-51.

Rodić, N. R. (1997). Latentna struktura motoričkih sposobnosti populacije na kraju starijeg školskog doba. Norma, 3(3), 205-221.

Sabo, E. (2002). Struktura motoričkog prostora i razlike u motoričkim sposobnostima dečaka predškolskog uzrasta pri upisu u osnovnu školu. Fizička kultura, 56(1-4), 10-17.

Shepard, R. J. (1982). Physical Activity and Growth. Chicago: Yearbook Medical Publication.

Strel, J., \& Šturm, J. (1981). Zaneseljivost in struktura nekaterih motoričnih sposobnosti in morfoloških značilnosti šest in pol letnih učencev in učenk. Ljubljana: Inštitut za kineziologijo.

Tomac, Z., Šumanović, M., \& Prskalo, I. (2012). Morphological Characteristics and Obesity Indicators in Primary School Children in Slavonia: Cross-Sectional Study. Croatian Journal of Education, 14(3), 657-680.

World Health Organization (2000). Obesity: preventing and managing the global epidemic. Technical Report Series, 894. Geneva: WHO.

Zaciorski, V. M. (1975). Fizička svojstva sportiste. Beograd: Savez za fizičku kulturu.

\section{Danimir Mandić}

Faculty of Teacher Education, University of Belgrade

Kraljice Natalije 43, 11000 Beograd, Serbia

danimir.mandic@uf.bg.ac.rs

\section{Dragan Martinović}

Faculty of Teacher Education, University of Belgrade

Kraljice Natalije 43, 11000 Beograd, Serbia

dragan.martinovic@uf.bg.ac.rs

\section{Vladan Pelemiš}

Faculty of Teacher Education, University of Belgrade

Kraljice Natalije 43, 11000 Beograd, Serbia

vladan.pelemis@uf.bg.ac.rs 


\section{Struktura motoričkih sposobnosti djece predškolske dobi prije i poslije kineziološkog tretmana}

\section{Sažetak}

Istraživanje je obavljeno na uzorku od 114 djece predškolske dobi starosti 6 i 7 godina s prosječnim vrijednostima tjelesne visine $(T V=123,23 \mathrm{~cm} \pm 5,43)$ i tjelesne težine (TT=24,53 kg士2,71), podijeljenih u dvije skupine i to: (E) eksperimentalnu ( $n=55)$ koja je imala dodatni program kinezioloških aktivnosti u trajanju od 12 tjedana $i(K)$ kontrolnu skupinu $(n=59)$ koja uz redovne aktivnosti iz Tjelesnog $i$ zdravstvenog odgoja u vrtiću nije imala dodatni program kinezioloških aktivnosti. Cilj istraživanja bio je utvrđivanje latentne strukture motoričkih sposobnosti prije i poslije tretmana kinezioloških aktivnosti, te utvrđivanje podudarnosti faktorskih zasićenja. Korelacija je izvršena s pomoću Pearson-ova koeficijenta korelacije, a utvrdivanje strukture motoričkih sposobnosti izvedeno je faktorskom analizom $i$ to metodom glavnih komponenti uz kosu promax rotaciju izoliranih glavnih komponenti. Tucker-ov indeks faktorskih zasićenja koristio se za određivanje podudarnosti izoliranih faktora. Rezultati istraživanja ukazuju na to da je na inicijalnom i na finalnom mjerenju u obje testirane skupine utvrđena dvodimenzionalna struktura motoričkih sposobnosti koju čine koordinacija $i$ snaga, a koju je najprikladnije definirati kao jedan $i$ to generalni motorički faktor. Kongruencije izmedu izoliranih faktora u $E$ i K skupini dobivenih na inicijalnom i finalnom mjerenju ukazuju na to da nema različitosti u strukturi izoliranih fakora. Zaključuje se da je motoričko funkcioniranje djece još uvijek pod dobrim dijelom mehanizma za strukturiranje kretanja, te se i nakon tretmana kinezioloških aktivnosti još uvijek radi o jednim te istim faktorima, a kvalitativne promjene u strukturi motoričkih sposobnosti ne postižu se u testiranoj dobi.

Ključne riječi: faktorska analiza; kineziološke aktivnosti; kongruencija izoliranih faktora; motoričke sposobnosti; predškolska djeca. 